\title{
Penerapan Analytical Hierarchy Process (AHP) Untuk Mempermudah Penentuan Kendaraan Pribadi
}

\author{
Hendra, Marzuki
}

\begin{abstract}
In today's modem ene the various topes of vehicles being producad to facititate a person in carrying out activities throughout the day. One of the vehicles chosen by a handful of people is a car that not anty con accommodate several people but also has a dual function that can accommodate leggage in the car. Surely it is not uncommon when someone is having difficulty in choosing the type of car he wanted. In this Final Project, the awthars want to design a simple web application using she analytical hierarchy process to select the type of car based on certaint criteria. Through the selection criteria that exist in the web opplication can be determined what kind of car that suits one's choice. This can be determined from charging an application that has been filled by a person in determining the type of criteria to match, Based on the derign of web applications is expected to be used for the selection of cars in accordance with appropriate criteria.
\end{abstract} Cars

Keywords-Decisian Suppourt Systems, Determination

\section{PENDAHULUAN}

Mobil merupakan salah satu jenis alat transportasi yang dipilih oleh segelintir orang karena jenis alat transportasi ini dapat menampung lebih dari satu penumpang dan memiliki kenyamanan dalam berkendara. Selain itu alat transportasi ini memiliki fungsi ganda, disamping dapat menampung lebih dari satu penumpang, dapat menampung barang bawaan dalam bagasi. Dalam memilih mobil baru maupun bekas, sescorang sulit menentukan mobil yang akan dipilihnya untuk digunakan dalam kehidupan sehari-bari. Karena mobil memiliki jenis dan kriteria yang berbeda-beda (jurnal penelitian Yonathan Christian Saununu, 2009).

Masalah tersebut dapat digolosghan ke dalam masalah yang multiobjectives (ada banyak tujuan yang ingin dicapai) dan multicriterias (ada banyak kriteria untuk mencapai mjuan). Maka dari itu perlu dibuat sistem penunjang keputusan untuk mengatasi masalah dalam pemilihan mobil baru maupun bekas.

\section{METODE PENELITIAN}

\section{I Analisa}

Dalam rangka menentukan prioritas penentuan mobil untuk seseorang, maka diusulkan terdapat tiga kriteria dan enam alternatif mobil yang mendukung proses penentuan. Adapan kriteria dan alternatif mobil dapat dirinci dalam tabel sebagai berikut :

TABEL I. KUTTERLA DAN ALTERNATIF MOBL

\begin{tabular}{|c|c|}
\hline Kriteria & $\begin{array}{l}\text { 1. Nyaman } \\
\text { 2. Harga } \\
\text { 3. Irit }\end{array}$ \\
\hline Altenatif & $\begin{array}{l}\text { 1. Chevrolet } \\
\text { 2. Honda } \\
\text { 3. Hyundai } \\
\text { 4. KIA } \\
\text { 5. Proton } \\
\text { 6. Toyota }\end{array}$ \\
\hline
\end{tabular}

Analytical Hierarchy Pracess (AHP) melakukan perbandingan berpasangan setiap alternatif dengan menggunakan skala saaty dari $1 / 9$ sampai dengan 9. Jika pilihan A dan B dianggap sama (indifferent), maka A dan B masing-masing diberi nilai 1 . Jika misalnya A agak lebih baik/agak lebih disukai dari B, maka A diberi nilai 3 dan $B$ diberi nilai 1/3. Jika A cukup disukai dari $\mathrm{B}$, maka A misalnya diberi nilai 5 dan $B$ diberi nilai $1 / 5$, jika $A$ sangat disukai dengan dari $\mathrm{B}$ maka $\mathrm{A}$ diberi nilai 7 dan B diberi nilai 17 , jika A amat sangat disukai dari $\mathrm{B}$ maka $\mathrm{A}$ diberi nilai 9 dan $\mathrm{B}$ diberi nilai 1/9. Sedangkan nilai $2,4,6,8$ adalah nilai tengah diantara dua nilai keputusan yang berdekatan. 
TABEL. PE,RBANDINGAN ANTAR ALTIERNATIE

\begin{tabular}{|c|c|c|c|c|c|c|}
\hline $\begin{array}{l}\text { Alte } \\
\text { mat } \\
\text { if } \\
\text { (A) }\end{array}$ & Al & A2 & A3 & A4 & A5 & A6 \\
\hline A1 & $\begin{array}{l}\mathrm{Al} \\
\mathrm{I}\end{array}$ & $\mathrm{A} 12$ & $\mathrm{~A} 13$ & $\mathrm{Al} 14$ & $\begin{array}{l}\text { Al } \\
5\end{array}$ & A16 \\
\hline $\mathrm{A} 2$ & $\begin{array}{l}\mathrm{A} 2 \\
1\end{array}$ & $\mathrm{~A} 22$ & A23 & A24 & $\begin{array}{l}\mathrm{A2} \\
5\end{array}$ & A26 \\
\hline A3 & $\begin{array}{l}\text { A3 } \\
1\end{array}$ & $A 32$ & A33 & $A 34$ & $\begin{array}{l}A 3 \\
5\end{array}$ & A36 \\
\hline A4 & $\begin{array}{l}\text { A4 } \\
I\end{array}$ & $\mathrm{~A} 42$ & A43 & A44 & $\begin{array}{l}\text { A4 } \\
5\end{array}$ & A46 \\
\hline AS & $\begin{array}{l}\text { A5 } \\
1\end{array}$ & $\mathrm{~A} 52$ & A53 & A54 & $\begin{array}{l}\text { A5 } \\
5\end{array}$ & A56 \\
\hline A6 & $\begin{array}{l}\text { A6 } \\
1\end{array}$ & A62 & A63 & A64 & $\begin{array}{l}\mathrm{A} 6 \\
5\end{array}$ & $A 66$ \\
\hline $\begin{array}{l}\text { Jum } \\
\text { lah } \\
\text { (J) }\end{array}$ & $\begin{array}{l}\mathrm{J} 1= \\
\mathrm{A} 1 \\
1+ \\
\mathrm{A} 2 \\
1+ \\
\mathrm{A} 3 \\
1+ \\
\mathrm{A} 4 \\
1+ \\
\mathrm{A} 5 \\
1+ \\
\mathrm{A} 6 \\
1\end{array}$ & $\begin{array}{l}\mathrm{J} 2= \\
\mathrm{A} 12 \\
+\mathrm{A} 2 \\
2+\mathrm{A} \\
32+ \\
\mathrm{A} 42 \\
+\mathrm{A} 5 \\
2+\mathrm{A} \\
62\end{array}$ & $\begin{array}{l}\mathrm{J3}= \\
\mathrm{A} 13 \\
+\mathrm{A} 2 \\
3+\mathrm{A} \\
33+ \\
\mathrm{A} 43 \\
+\mathrm{A} 5 \\
3+\mathrm{A} \\
63\end{array}$ & $\begin{array}{l}J 4= \\
\text { A14 } \\
+A 2 \\
4+A \\
34+ \\
\text { A44 } \\
+A 5 \\
4+A \\
64\end{array}$ & $\begin{array}{l}\text { J5 } \\
= \\
\text { A1 } \\
5+ \\
\text { A2 } \\
5+ \\
\text { A3 } \\
5+ \\
\text { A4 } \\
5+ \\
\text { A5 } \\
5+ \\
\text { A6 } \\
5\end{array}$ & $\begin{array}{l}\mathrm{J} 6= \\
\mathrm{A} 16 \\
+\mathrm{A} 2 \\
6+\mathrm{A} \\
36+ \\
\mathrm{A} 46 \\
+\mathrm{A} 5 \\
6+\mathrm{A} \\
66\end{array}$ \\
\hline
\end{tabular}

Setelah perbandingan antar aiternatif terselesaikan maka dilanjutkan dengan cara menghitung nilai Eigenvector Utama setiap alternatif. Eigenvector utama adalah bobot nilai rata-rata secara keseluruhan yang diperoleh dari rata-rata masing-masing faktor dari setiap. barisnya.

TABEL 3

TABEL ETCENVECTOR

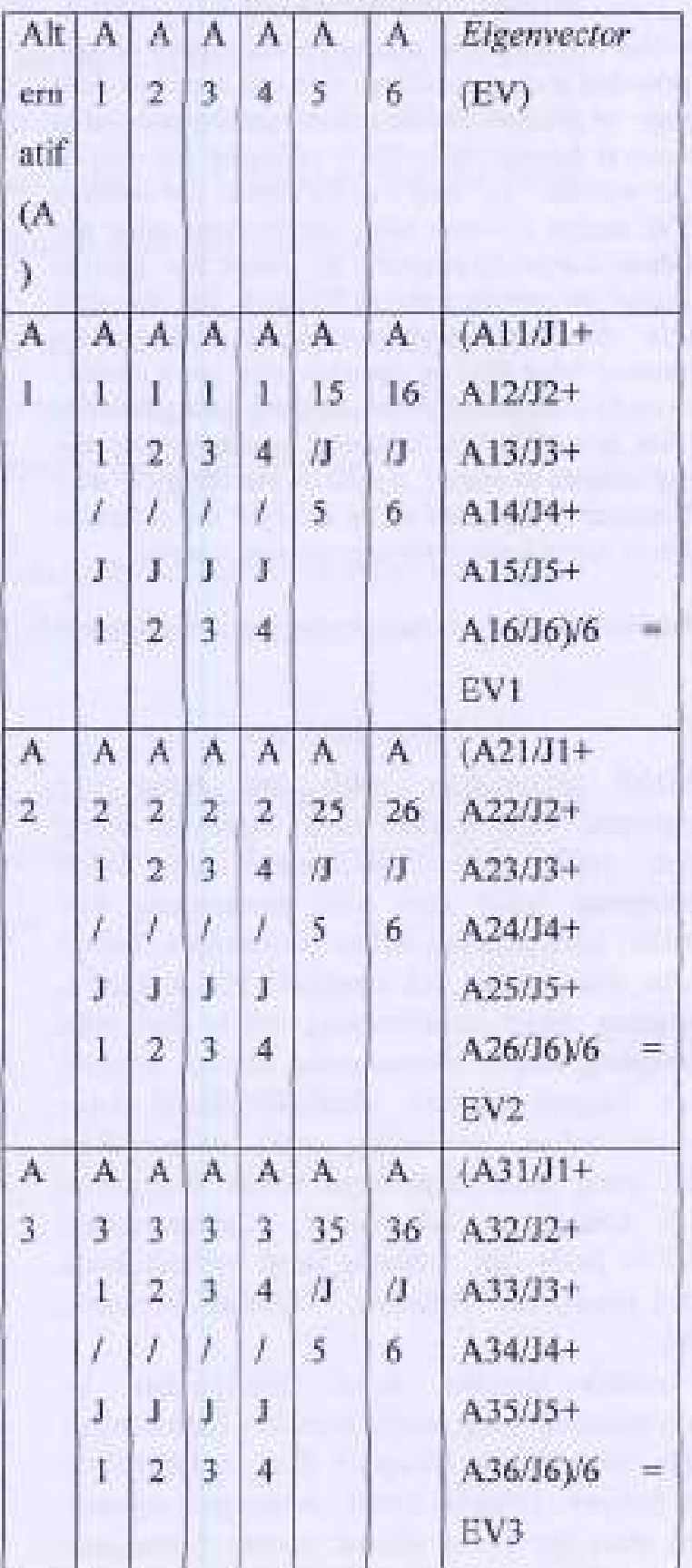




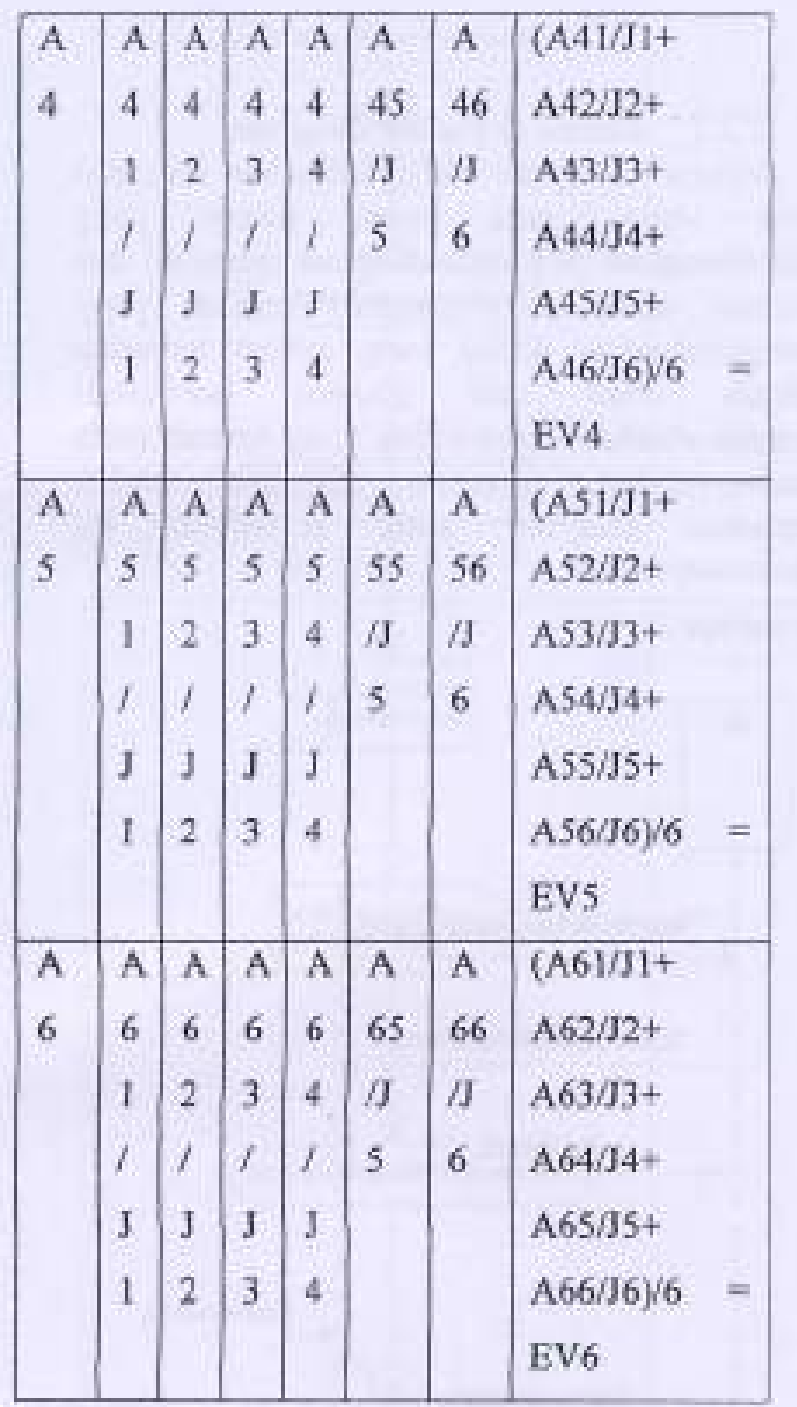

Untuk mendapatkan hasil akhir persentase setiap altematif, maka nilai eigemvector utama setiap kriteria dirata-rata.

TABEL 4

TABEL RATA-RATA ENOENVECTDR

\begin{tabular}{|l|l|l|l|l|l|l|}
\hline $\begin{array}{l}\text { Alt } \\
\text { em } \\
\text { atif }\end{array}$ & A1 & A2 & A3 & A4 & A5 & A6 \\
\hline $\begin{array}{l}\text { Kri } \\
\text { teri }\end{array}$ & EV1 & EV2 & EV3 & EV4 & EV5 & EV6 \\
a 1 & $\begin{array}{l}\text { krite } \\
\text { rial }\end{array}$ & $\begin{array}{l}\text { krite } \\
\text { rial }\end{array}$ & $\begin{array}{l}\text { krite } \\
\text { rial }\end{array}$ & $\begin{array}{l}\text { krite } \\
\text { rial }\end{array}$ & krite & krite \\
rial \\
\hline
\end{tabular}

\begin{tabular}{|c|c|c|c|c|c|c|}
\hline $\begin{array}{l}\text { Kri } \\
\text { teri } \\
\text { a } 2\end{array}$ & $\begin{array}{l}\text { EVI } \\
\text { krite } \\
\text { ria2 }\end{array}$ & $\begin{array}{l}\text { EV2 } \\
\text { krite } \\
\text { rin2 }\end{array}$ & $\begin{array}{l}\text { EV3 } \\
\text { krite } \\
\text { ria2 }\end{array}$ & $\begin{array}{l}\text { EV4 } \\
\text { krite } \\
\text { ria2 }\end{array}$ & $\begin{array}{l}\text { EV5 } \\
\text { krite } \\
\text { ria2 }\end{array}$ & $\begin{array}{l}\text { EV6 } \\
\text { krite } \\
\text { ria2 }\end{array}$ \\
\hline $\begin{array}{l}\text { Kri } \\
\text { teri } \\
\text { a } 3\end{array}$ & $\begin{array}{l}\text { EVI } \\
\text { krite } \\
\text { ria3 }\end{array}$ & $\begin{array}{l}\text { EV2 } \\
\text { krite } \\
\text { ria } 3\end{array}$ & $\begin{array}{l}\text { EV3 } \\
\text { krite } \\
\text { ria3 }\end{array}$ & $\begin{array}{l}\text { EV4 } \\
\text { krite } \\
\text { ria3 }\end{array}$ & $\begin{array}{l}\text { EV5 } \\
\text { krite } \\
\text { ria3 }\end{array}$ & $\begin{array}{l}\text { EV6 } \\
\text { krite } \\
\text { ria3 }\end{array}$ \\
\hline $\begin{array}{l}J_{11} \\
\mathrm{ml} \\
\mathrm{ah}\end{array}$ & $\begin{array}{l}\text { (EV } \\
1, \\
\text { krite } \\
\text { rial } \\
+E V \\
1, \\
\text { krite } \\
\text { ria2 } \\
+E V \\
1, \\
\text { krite } \\
\text { ria3) } \\
\text { B }\end{array}$ & $\begin{array}{l}\text { (EV } \\
2, \\
\text { krite } \\
\text { rial } \\
+E V \\
2, \\
\text { krite } \\
\text { ria2 } \\
+E V \\
2, \\
\text { krite } \\
\text { ria3) } \\
/ 3\end{array}$ & $\begin{array}{l}\text { (EV } \\
3, \\
\text { krite } \\
\text { rial } \\
+\mathrm{EV} \\
3, \\
\text { krite } \\
\text { ria2 } \\
+\mathrm{EV} \\
3, \\
\text { krite } \\
\text { ria3) } \\
13\end{array}$ & $\begin{array}{l}\text { (EV } \\
4, \\
\text { krite } \\
\text { rial } \\
+ \text { EV } \\
4, \\
\text { krite } \\
\text { ria2 } \\
+E V \\
4, \\
\text { krite } \\
\text { ria3) } \\
13\end{array}$ & $\begin{array}{l}\text { (EV } \\
5, \\
\text { krite } \\
\text { rial } \\
+ \text { EV } \\
5, \\
\text { krite } \\
\text { ria2 } \\
+ \text { EV } \\
5, \\
\text { krite } \\
\text { ria3) } \\
\text { 3 }\end{array}$ & $\begin{array}{l}\text { (EV } \\
6, \\
\text { krite } \\
\text { rial } \\
+\mathrm{EV} \\
6, \\
\text { krite } \\
\text { ria2 } \\
+\mathrm{EV} \\
6, \\
\text { krite } \\
\text { ria3) } \\
8\end{array}$ \\
\hline
\end{tabular}

\subsection{Arsitektur}

Di dalam melakukan perancangan penelitian, penulis melakukan 2 tahap yaitu:

1. Penulis mendapatkan data atan fakta yang bersifat teoritis yang berkaitan dengan cara mempelajari literaturliterntur, jurnal-jurnal penelitian, bahan kulish dan sumber lain

2. Penulis melakukan perancangan output atau hasil dalam bentuk program dengan cara membuat UML dan merancang desain tampilan program.

\subsubsection{Desain Use Case Diagram}

Diagram use case menggambarkan interaksi antara sistem dan pengguna. 


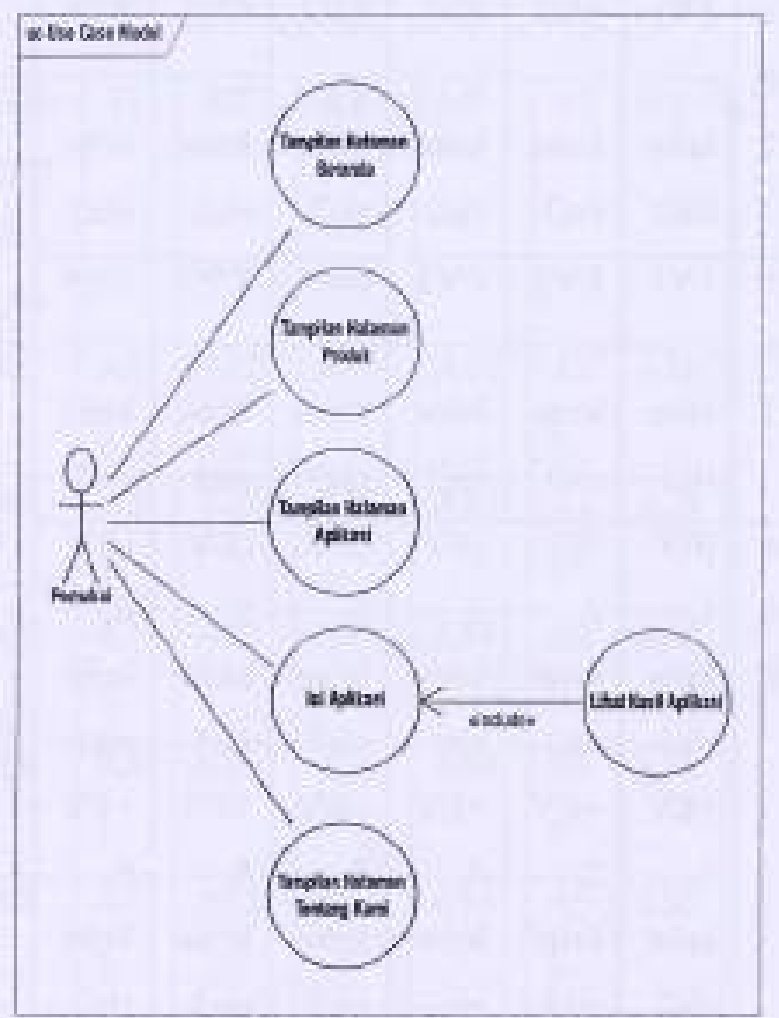

Gimbar 1. Ulse Case Diagrave

\subsubsection{Desain Class Diagram}

Class diagram menggambarkan struktur dan deskripsi class, packago dan objek beserta hubungan satu sama lain. Pada Penelitian ini dapat digambarkan class diagram sistem sebagai berikut:

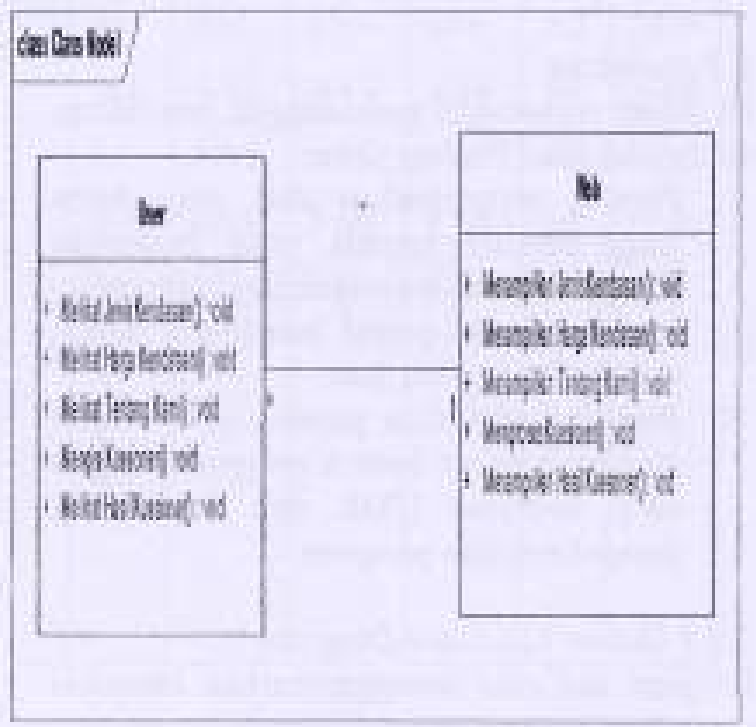

Cianbar 2

Closs Dowanat

\subsubsection{Desain Sequence Diagram}

Sequence diagram menggambarkan interaksi antar objek pada suatu sistem yang dikembangkan. Seguence diagram memiliki daa dimensi utama yaitu dimensi vertikal yang menggambarkan waktu yang terkait terhadap sebuah objek dan dimensi horizontal menggambarkan objek-objek yang terkait pada masing-masing diagram. Berikut adalah sequence diagram pada penelitian ini diantaranya lain:

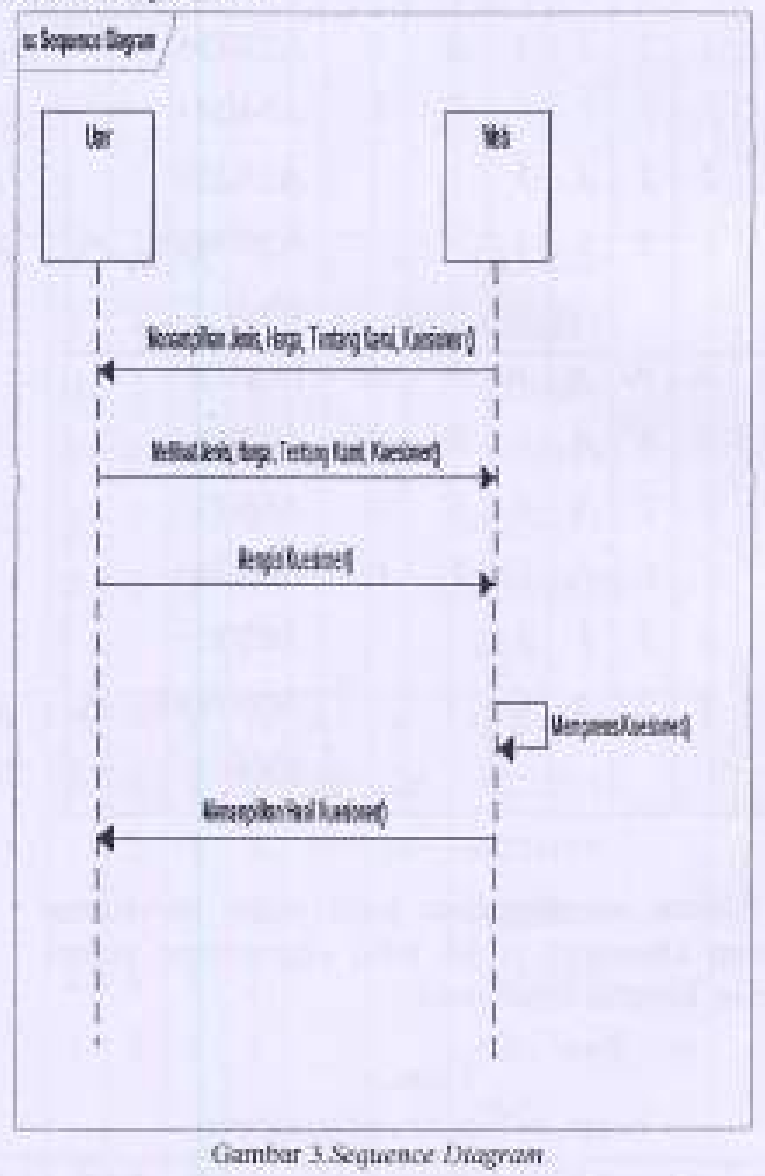

\subsubsection{Desain Activity Diagram}

Activity diagram menggambarkan berbagai flow (aliran) aktivitas dalam sistem yang sedang dirancang. Activity diagram juga dapat menggambarkan awalan suatu ahtivias, percabangan (decission) sampai pada tahapan ahir suatu aktivitas sistem. Berikut adalah Activity Diagrams yang menggambarkan aktivitas yang terjadi pada aplikasi ini: 


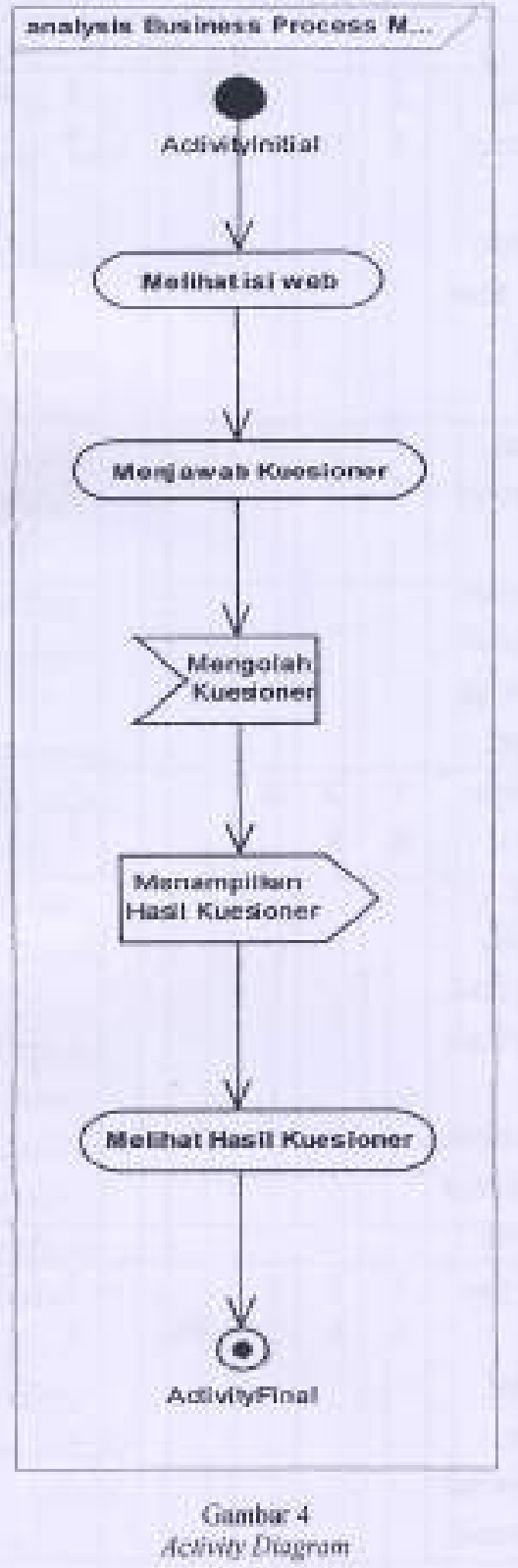

\subsection{Merode Penyelesaian}

Salah satu metode yang akan digunakan dalam sistem penunjang keputusan ini dengan menggunakan Analitycal Hierarchy Process (AHP). Salah satu bentuk pengambilan keputusan dengan multiple kriteria. Analyical Hierarchy Process (AHP) diperkenalkan oleh Thomas L. Saaty pada periode 1971-ketika di Wharton School. Pada dasarnya Analysical Hieranchy Process (AHP) adalah teori umum tentang pengukuran. Analytical Hierarchy Process $(A H P)$ digunakan untuk menentukan shala rasio, baik dari perbandingan pasangan yang diskrit maupun yang kontinyu. Pertandingan yang digunakan dari ukuran aktual atau dari suatu skala dasar yang mencerminkan kekuatan perasaan dan preferensi relatif (Siti Latifah, 2005 : p1). Penggunaan teori ini diharapkan dapat menyelesaikan permasalahan di atas.

\subsubsection{Pengukuran Penelitian:}

Penyebaran kuesioner perbandingan tingkat kepuasan, ketepatan, kemudahan dalam penentuan kendaraan pribadi dilakukan dengan cara menyebarkan kuesioner terhadap 10 orang . Tujuan dilakukan survey untuk mengetahui perubahan yang terjadi sebelum dan sesudah implementasi sistem.

Berikut adalah hasil nilai dari kuesioner beserta grafik hasil :

\section{Tingkat Kepuasan}

Seperti penjelasan di atas, seberapa puaskah anda pada saat menentukan jenis mobil berdasarkan kriteria (nyaman, irit, harga) ?

TABELS

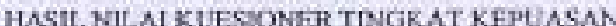

\begin{tabular}{|c|c|c|c|c|c|c|c|}
\hline \multirow[t]{2}{*}{ No. } & \multirow{2}{*}{$\begin{array}{c}\text { Segi } \\
\text { Kepuasan } \\
\text { Anda }\end{array}$} & \multicolumn{4}{|c|}{$\begin{array}{l}\text { Tingkat } \\
\text { Kepuasan }\end{array}$} & \multirow[b]{2}{*}{$\stackrel{*}{N}$} & \\
\hline & & $\begin{array}{l}\text { S } \\
\text { P }\end{array}$ & & & $\mathrm{TP}$ & & $\%$ \\
\hline 1. & $\begin{array}{l}\text { Mennilih } \\
\text { jenis mobil } \\
\text { yang ada di } \\
\text { berbagai } \\
\text { media } \\
\text { informasi } \\
\text { (brosur, } \\
\text { majalah, } \\
\text { televisi, } \\
\text { dsb) }\end{array}$ & $\begin{array}{l}1 \\
0\end{array}$ & \begin{tabular}{l|l}
2 &. \\
0
\end{tabular} & \begin{tabular}{|l|l|}
3 \\
\end{tabular} & 1 & $\begin{array}{l}3 \\
6\end{array}$ & $\begin{array}{l}7 \\
2\end{array}$ \\
\hline 2. & $\begin{array}{l}\text { Melihat } \\
\text { langsung } \\
\text { ke } \\
\text { showroom } \\
\text { atau dealer } \\
\text { mobil }\end{array}$ & $\begin{array}{l}3 \\
0\end{array}$ & $\begin{array}{l}1 \\
2\end{array}$ & 3) & & $\begin{array}{l}4 \\
5\end{array}$ & $\begin{array}{l}9 \\
0\end{array}$ \\
\hline
\end{tabular}




\begin{tabular}{|c|c|c|c|c|c|c|}
\hline 3. & $\begin{array}{l}\text { Mencari } \\
\text { informasi - } \\
\text { informasi } \\
\text { melalui } \\
\text { teknologi } \\
\text { internet }\end{array}$ & $\begin{array}{l}1 \\
0\end{array}$ & \begin{tabular}{l|}
2 \\
8
\end{tabular} & 3] & $\begin{array}{l}4 \\
1\end{array}$ & $\begin{array}{l}8 \\
2\end{array}$ \\
\hline 4. & $\begin{array}{l}\text { Bertanya } \\
\text { kepsda } \\
\text { teman } \\
\text { kerabat, } \\
\text { atau pihak } \\
\text { yang pihak } \\
\text { memahami } \\
\text { dunia } \\
\text { otomotif }\end{array}$ & $\begin{array}{l}1 \\
0\end{array}$ & \begin{tabular}{l|}
2 \\
0
\end{tabular} & 9 & $\begin{array}{l}3 \\
9\end{array}$ & $\begin{array}{l}7 \\
8\end{array}$ \\
\hline 5. & $\begin{array}{l}\text { Mengguna } \\
\text { kan } \\
\text { aplikasi } \\
\text { sistem } \\
\text { penunjang } \\
\text { keputusan }\end{array}$ & $\begin{array}{l}1 \\
0\end{array}$ & $\begin{array}{l}2 \\
0\end{array}$ & 9 & & $\begin{array}{l}7 \\
8\end{array}$ \\
\hline
\end{tabular}

\section{Tingkat Ketepatan}

Seperti penjelasan di atas, apakah sudah tepat pada saat anda menentukan jenis mobil berdasarkan kriteria (nyaman, irit, harga)?

TABHL, 6

HASIL, NILAIKUESIONER TINGKAT KETEPATAN

\begin{tabular}{|c|c|c|c|c|c|c|c|c|}
\hline $\mathrm{N}$ & Segi & & $g k:$ & K & ep: & & & \\
\hline o. & Ketepatan & $\mathrm{S}$ & C & B & K & $\mathbf{T}$ & $\cdot$ & • \\
\hline . & Anda & $T$ & $\mathrm{~T}$ & S & $T$ & $\mathrm{~T}$ & $\mathrm{~N}$ & $\%$ \\
\hline 1 & Memilih & 1 & 1 & 6 & 4 & & 3 & 72 \\
\hline . & jenis & 0 & 6 & & & & 6 & \\
\hline & mobil & & & & & & & \\
\hline & yang ada & & & & & & & \\
\hline & & & & & & & & \\
\hline & berbagni & & & & & & & \\
\hline & media & & & & & & & \\
\hline & informasi & & & & & & & \\
\hline & (brosur, & & & & & & & \\
\hline & $\begin{array}{l}\text { majalah, } \\
\text { televisi, }\end{array}$ & & & & & & & \\
\hline
\end{tabular}

\begin{tabular}{|c|c|c|c|c|c|c|c|}
\hline & dsb) & & & & & & \\
\hline 2 & $\begin{array}{l}\text { Melihat } \\
\text { langsung } \\
\text { ke } \\
\text { showroo } \\
m \quad \text { atau } \\
\text { dealer } \\
\text { mobil }\end{array}$ & $\begin{array}{l}2 \\
5\end{array}$ & $\begin{array}{l}2 \\
0\end{array}$ & & 2 & $\begin{array}{l}4 \\
7\end{array}$ & 94 \\
\hline 3 & $\begin{array}{l}\text { Mencari } \\
\text { informasi } \\
\text { informasi } \\
\text { melalui } \\
\text { teknologi } \\
\text { internet }\end{array}$ & $\begin{array}{l}1 \\
0\end{array}$ & $\begin{array}{l}2 \\
0\end{array}$ & 9 & & $\begin{array}{l}3 \\
9\end{array}$ & 78 \\
\hline 4 & $\begin{array}{l}\text { Bertanya } \\
\text { kepada } \\
\text { teman } \\
\text { kerabat, } \\
\text { atau pihak } \\
\text { yang pihak } \\
\text { memaham } \\
\text { i dunia } \\
\text { otomotif }\end{array}$ & $\begin{array}{l}1 \\
0\end{array}$ & $\begin{array}{l}2 \\
8\end{array}$ & 3 & & $\begin{array}{l}4 \\
1\end{array}$ & 82 \\
\hline 5 & $\begin{array}{l}\text { Menggun } \\
\text { akan } \\
\text { aplikasi } \\
\text { sistem } \\
\text { penunjang } \\
\text { keputusan }\end{array}$ & $\begin{array}{l}\mathrm{T} \\
0\end{array}$ & $\begin{array}{l}1 \\
6\end{array}$ & $\begin{array}{l}1 \\
2\end{array}$ & & $\begin{array}{l}3 \\
8\end{array}$ & 76 \\
\hline
\end{tabular}

\section{Tingkat Kemudahan}

Seperti penjelasan di atas,seberapa mudahkah andr pada saat menentukan jenis mobil berdasarkan kriteria (nyaman, irit, harga)?

TABFL 7

HASIL. NII AI KUESIONERR TINGKAT KEMUDAHAN

\begin{tabular}{|c|c|c|c|c|c|c|c|}
\hline \multirow[t]{3}{*}{$\begin{array}{l}\mathrm{N} \\
\text { o. }\end{array}$} & \multirow{3}{*}{$\begin{array}{c}\text { Segi } \\
\text { Kemudaha } \\
\text { п Anda }\end{array}$} & \multicolumn{4}{|c|}{$\begin{array}{l}\text { Tingkat } \\
\text { Kemudahan }\end{array}$} & \multirow{3}{*}{$\begin{array}{l}{ }^{*} \\
V\end{array}$} & \multirow{3}{*}{$\$ \%$} \\
\hline & & S & C & B & K T & & \\
\hline & & $M$ & $\mathrm{M}$ & $\mathrm{S}$ & $M M$ & & \\
\hline
\end{tabular}




\begin{tabular}{|c|c|c|c|c|c|c|c|c|}
\hline 1. & $\begin{array}{l}\text { Memilih } \\
\text { jenis } \\
\text { mobil } \\
\text { yang ada } \\
\text { di } \\
\text { berbagai } \\
\text { media } \\
\text { informasi } \\
\text { (brosur, } \\
\text { majalah, } \\
\text { televisi, } \\
\text { dsb) }\end{array}$ & $\begin{array}{l}2 \\
0\end{array}$ & $\frac{1}{6}$ & 6 & & & $\begin{array}{l}4 \\
2\end{array}$ & 84 \\
\hline 2. & $\begin{array}{l}\text { Melihat } \\
\text { langsung } \\
\text { ke } \\
\text { showroom } \\
\text { atau dealer } \\
\text { mobil }\end{array}$ & $\begin{array}{l}2 \\
0\end{array}$ & $\begin{array}{l}1 \\
6\end{array}$ & 6 & & & $\begin{array}{l}4 \\
2\end{array}$ & 84 \\
\hline 3. & $\begin{array}{l}\text { Mencan } \\
\text { informasi } \\
\text { - } \\
\text { informasi } \\
\text { melalui } \\
\text { teknologi } \\
\text { internet }\end{array}$ & $\begin{array}{l}1 \\
5\end{array}$ & $\begin{array}{l}2 \\
8\end{array}$ & & & & $\begin{array}{l}4 \\
3\end{array}$ & 86 \\
\hline 4. & $\begin{array}{l}\text { Bertanya } \\
\text { kepada } \\
\text { teman } \\
\text { kerabat, } \\
\text { atau pihak } \\
- \text { pihak } \\
\text { yang } \\
\text { memaham } \\
\text { i dunia } \\
\text { otomotif }\end{array}$ & 5 & $\begin{array}{l}3 \\
2\end{array}$ & & & 1 & $\begin{array}{l}3 \\
8\end{array}$ & 76 \\
\hline 5. & $\begin{array}{l}\text { Mengguna } \\
\text { kan } \\
\text { aplikasi } \\
\text { sistean } \\
\text { penunjang } \\
\text { keputusan }\end{array}$ & $\begin{array}{l}1 \\
0\end{array}$ & 4 & $\begin{array}{l}1 \\
2\end{array}$ & 6 & 1 & $\begin{array}{l}3 \\
3\end{array}$ & 66 \\
\hline
\end{tabular}

$$
\begin{aligned}
& * \mathrm{~N}=\text { jumlah jawaban dari kuesioner } \\
& * \%=\frac{\mathrm{N} \times 100}{50}
\end{aligned}
$$

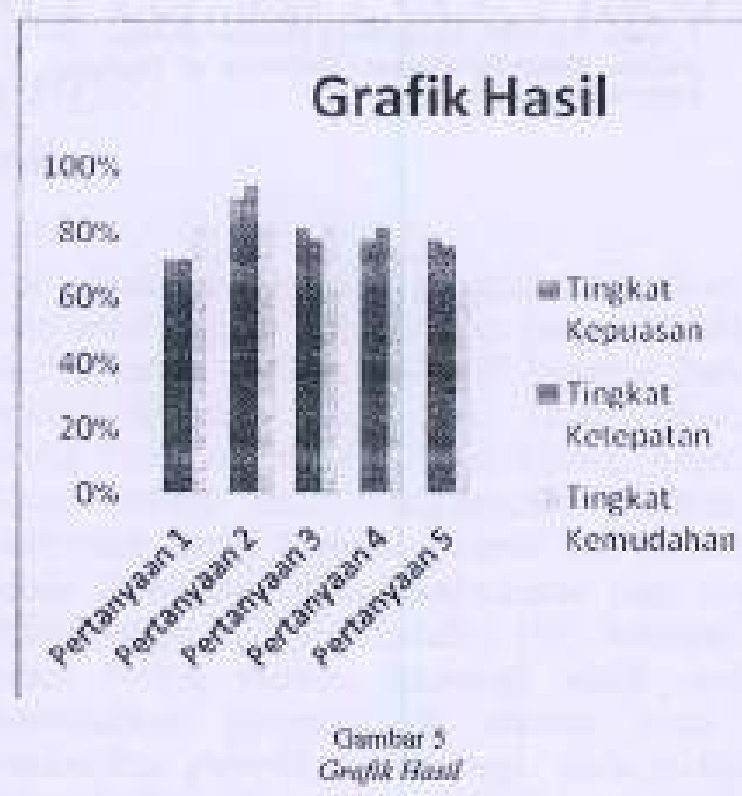

\section{KestMPULAN}

Berdasarkan penelitian yang dibuat maka dapat diambil kesimpulan sebagai berikut:

1. Pada tingkat kepuasan, sebesar $78 \%$ seseorang puas dalam penentuan kendaraan.

2. Dalam tingkat ketepatan, sebesar $76 \%$ aplikasi tersebut tepat dalam menentukan kendaraan.

3. Sedangkan pada tingkat kemudahan, hanya sekitar $66 \%$ memudahkan seseorang dalam menentukan kendaraan pribadi.

\section{SARAN}

Dari hasil penelitian dan maka saran yang diusulkan adalah sebagai berikut :

1. Penentuan kendaraan pribadi ini tentunya dapat dikembangkan ke tahapan yang lebih kompleks dan terperinci.

2. Sistem pendukung keputusannya pun dapat dikembangkan bukan hanya untuk penentuan kendaraan pribadi saja tetapi dalam penentuan sparepart kendaraan, dsb. 


\section{DAFTAR PUSTAKA}

[1] Ssacy, T.L. 2001. Decissin Makigg For Leaders. Forth edition, University of Pitsburgh. RWS Publezaion.

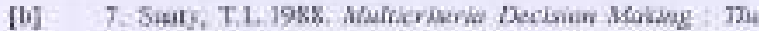

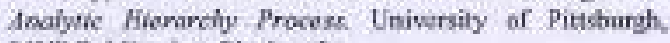
RWS Publication, Pittdourgh 